\title{
Inhibition of Apoptosis and Virus Replication in Feline Immunodeficiency Virus- Infected Cells by N-Acetylcysteine and Ascorbic Acid
}

\author{
Eduardo MORTOLA, Masaru OKUDA, Ko-ichi OHNO ${ }^{1)}$, Toshihiro WATARI, Hajime TSUJIMOTO* and \\ Atsuhiko HASEGAWA \\ Department of Veterinary Internal Medicine, Graduate School of Agricultural and Life Sciences, The University of Tokyo, Bunkyo-ku, \\ Tokyo 113-8657 and ${ }^{1)}$ Laboratory of Veterinary Internal Medicine, Faculty of Agriculture, Yamaguchi University, Yamaguchi 753- \\ 8515, Japan
}

(Received 2 April 1998/Accepted 1 July 1998)

ABSTRACT. Infection of feline immunodeficiency virus (FIV) has been shown to induce apoptosis that might be associated with the lymphocyte depletion in the infected cats. To investigate the inhibitory effect of antioxidants on FIV-induced apoptosis, we examined the effect of N-acetylcysteine (NAC) and ascorbic acid (AA) on apoptosis and virus replication in feline lymphoblastoid (Fel-039) and fibroblastoid (CRFK) cell lines infected with FIV. The treatment with NAC or AA induced a significant inhibition of viral replication and apoptosis in Fel-039 cells and tumor necrosis factor $\alpha$ (TNF- $\alpha$ ) - treated CRFK cells infected with FIV. Both cell lines in the presence of noncytotoxic concentrations of NAC or AA showed an increase of intracellular glutathione (GSH) level, which might protect the cells against oxidative stresses exerted by FIV infection and TNF- $\alpha$ treatment. On the basis of these in vitro results, we suggest that antioxidant therapies aimed at restoring depleted GSH level might be effective for inhibition of viral replication and cell death associated with the development of immunodeficiency. — KEY wORDS: apoptosis, ascorbic acid, FIV, N-acetylcysteine.

J. Vet. Med.Sci. 60(11): 1187-1193, 1998

Feline immunodeficiency virus (FIV) was first isolated from immunodeficient cats in 1987 [32]. The cats infected with FIV show a variety of clinical and pathological findings similar to those in humans infected with human immunodeficiency virus (HIV) [31, 32], indicating that infection in cats may be useful as a small animal model for human AIDS.

Experimental infection of cats with FIV is followed by an acute phase (AP) for several weeks to months and an asymptomatic carrier (AC) stage for many years. Some of the FIV-infected cats may subsequently develop AIDSrelated complex (ARC) and AIDS in which a variety of clinical signs including weight loss, chronic infection, neoplasia, diarrhea and neurologic disease are observed $[11,42]$. Inversion of the CD4+/CD8+ T-lymphocyte ratio and suppression of lymphocyte blastogenesis have been demonstrated in these cats infected with FIV [1, 22].

FIV can replicate in feline peripheral blood mononuclear cells (PBMC), lymphoblastoid cell lines and a fibroblastoid cell line (CRFK) [7, 28, 32, 41]. Replication of FIV with or without treatment of tumor necrosis factor a (TNF- $\alpha)$, has been shown to induce apoptosis in these culture cells [29]. Cells undergoing apoptosis display profound structural changes including shrinkage of the cells, condensation of nuclear chromatin and formation of apoptotic bodies, which are associated with DNA cleavage into multiple fragments of approximately $200 \mathrm{bp}$ [42].

* Correspondence to: Dr. Tsujimoto, H., Department of Veterinary Internal Medicine, Graduate School of Agricultural and Life Sciences, The University of Tokyo, 1-1-1 Yayoi, Bukyo-ku,Tokyo 113-8657, Japan.
Many of the pathological aspects in HIV infection are not directly due to the viral replication, rather, they are secondary effects due to the host responses to the infection. One of the important aspects of this disease is the chronic inflammatory and oxidative stresses accompanied by the infection [35]. Eck et al. [12] demonstrated that HIVinfected individuals had decreased levels of thiols in their blood as a possible association between this oxidative stress and AIDS.

Reactive oxygen intermediate (ROI) seems to play an important role in the induction of apoptosis as indicated by several reports [23, 32, 36]. Fuchs et al. [15] reported that pro-oxidants such as neopterin, released by activated macrophages, may trigger apoptosis by destabilizing the equilibrium between oxidants and antioxidants. Gorman et al. [16] supported the hypothesis that oxidative stress and damage by free radicals may play an important role in the development of apoptosis in neurodegenerative diseases. Several reports also have indicated that processes of apoptosis may be linked to "oxidative stress" in HIV infection [17, 24]. From these finding, the regulation of cellular redox status may appear to be a key component which is responsible for the induction of apoptosis [23].

Glutathione (GSH), a tripeptide consisting of glutamic acid, cysteine and glycine, is one of the important intracellular defense systems against oxidative stresses. Through the thiol group of cysteine, GSH maintains a reducing environment and therefore protects the intracellular constituents from oxidative stress. As a substrate for the glutathione peroxidase enzyme, GSH removes the intracellular oxygen free radicals [10]. These observations led to the following suggestion that treatment with 
antioxidants may inhibit the apoptosis via decrease of the free radical production [10] and restoration of intracellular GSH [18, 34].

$\mathrm{N}$-acetylcysteine (NAC) is a thiol-containing compound that has been used for many years in the treatment of chronic bronchitis in humans [5, 6], and its mucolytic activity is mainly related to antioxidant properties [27] exerted directly by sulfite groups or as a result of an increase in the intracellular and plasma levels of cysteine, which is a precursor of glutathione [12]. Ascorbic acid (AA) is also an antioxidant which has been shown to inactivate a broad spectrum of viruses and to inhibit viral replication in the infected cells [30, 37].

In this experiment, we studied the effects of NAC and AA on apoptosis and viral replication in FIV-infected cells to develop a new strategy for the treatment of immunodeficiency in FIV infection.

\section{MATERIALS AND METHODS}

Cell lines: Feline fibroblastic cell line (CRFK) [8] and the same line chronically infected with Petaluma strain of FIV (CRFK/FIV) were used for the experiment. These cells were maintained in RPMI 1640 supplemented with $10 \%$ fetal calf serum. A feline T-lymphoblastoid cell line (Fel039) [41] was also used for this experiment, and was maintained in RPMI 1640 supplemented with $10 \%$ fetal calf serum, $50 \mathrm{mM}$ 2-mercaptoethanol, and $100 \mathrm{U}$ of recombinant human interleukin-2 per $\mathrm{m} l$. The viability of the culture cells was determined by staining with $0.4 \%$ trypan blue solution.

Treatments with NAC and AA: The stock solutions of 0.1 M NAC (Aldrich Chemical, Milwaukee, WI) and $0.06 \mathrm{M}$ AA (Sigma Chemical, St. Louis, MO) were dissolved in RPMI 1640 medium and stored at $-20^{\circ} \mathrm{C}$. The $\mathrm{pH}$ of the NAC solution was adjusted to 7.0 with $\mathrm{NaOH}$. Since both of the antioxidants are unstable in conventional culture conditions [4], fresh antioxidants prepared in the growth medium were given to the cell culture daily. The cell lines suspended at a density of $5 \times 10^{5}$ cells $/ \mathrm{m} l$ in the growth medium were cultured in the presence of NAC $(10-60 \mathrm{mM})$ or AA $(10-640 \mu \mathrm{g} / \mathrm{m} l)$.

Infection with FIV: The Fel-039 cell line, which is highly permissive to FIV replication, was infected with FIV of Petaluma strain [26] derived from the supernatant of CRFK/ FIV cell culture. The supernatant concentrated by ultracentrifugation was inoculated into Fel-039 cell culture at a multiplicity of infection of $10 \mathrm{TCID}_{50} /$ cell. After incubation for $24 \mathrm{hr}$, the cells were washed with the complete medium and then cultured at a density of $5 \times 10^{5}$ cells $/ \mathrm{ml}$ in fresh medium with or without antioxidants.

Determination of glutathione $(G S H)$ : Measurement of intracellular GSH was carried out according to the method of Tietze [40]. Briefly, cells were rinsed twice with phosphate buffered saline (PBS), pelleted by centrifugation at $800 \mathrm{~g}$ for $10 \mathrm{~min}$, lysed with $5 \%$ trichloroacetic acid and centrifuged at 2,000 $\mathrm{g}$ for $20 \mathrm{~min}$. The resultant supernatant
$(100 \mu l)$ was mixed with $200 \mu l$ of $0.3 \mathrm{M}$ Tris- $\mathrm{HCl} \mathrm{pH} 8$ and $5 \mu l$ of DTNB (5,5'-dithiobis-2-nitrobenzoic acid), and the absorbance at $450 \mathrm{~nm}$ was measured with an automatic microplate reader. This assay retained linearity at concentrations of GSH as low as $100 \mathrm{ng} / \mathrm{ml}$.

Reverse transcriptase (RT) assay: Virus particles in culture supernatant were pelleted by ultracentrifugation at $100,000 \mathrm{~g}$ for $30 \mathrm{~min}$ after removal of the cell debris by centrifugation at $8,000 \mathrm{~g}$ for $10 \mathrm{~min}$. The resulting pellets were assayed for the detection of RT activity by incorporation of digoxigenin labeled dUTP into DNA (Boehringer Mannheim, Mannheim, Germany).

DNA fragmentation assay: Approximately $5 \times 10^{6}$ cells collected from the culture were washed twice in PBS, and then pelleted by centrifugation at $600 \mathrm{~g}$ for $5 \mathrm{~min}$. The pellet was resuspended in a lysis buffer containing $1 \mathrm{mM}$ Tris- $\mathrm{HCl} \mathrm{pH} 7.4,1 \mathrm{mM}$ EDTA, $0.5 \%$ Triton X-100 and 0.5 $\mathrm{mg}$ of proteinase $\mathrm{K}$ per $\mathrm{m} l$ and then incubated at room temperature for $1 \mathrm{hr}$. After centrifugation at 13,000 $\mathrm{g}$ for $15 \mathrm{~min}$, the supernatant was extracted with phenol/ chloroform, precipitated with ethanol at $-20^{\circ} \mathrm{C}$, and then resuspended in TE buffer $(10 \mathrm{mM}$ Tris- $\mathrm{HCl} \mathrm{pH} 8$ and $1 \mathrm{mM}$ EDTA). The DNA sample was subjected to electrophoresis in $1.8 \%$ agarose gel containing ethidium bromide $(0.4 \mu \mathrm{g} /$ $\mathrm{m} l)$.

\section{RESULTS}

Effects of NAC and AA on CRFK cells infected with FIV: Before the evaluation of the effects of NAC and AA, we evaluated the cytotoxicity of both antioxidants in CRFK cells. No toxicity was observed when cells were grown in the presence of 10 to $30 \mathrm{mM}$ of NAC, or 20 to $80 \mu \mathrm{g}$ of AA per $\mathrm{m} l$ (data not shown). The concentrations of $15 \mathrm{mM}$ $\mathrm{NAC}$ and $60 \mathrm{mg}$ of AA per $\mathrm{ml}$ were chosen for the experiments.

As shown in Fig. 1A, cell death was rapidly induced in CRFK/FIV cells after treatment with TNF- $\alpha(100 \mathrm{U} / \mathrm{m} l)$. In the $24 \mathrm{hr}$ following exposure to TNF- $\alpha$, the cell viability of CRFK/FIV markedly declined to $51.1 \%$. Even after treatment with TNF- $\alpha$, the viability of the FIV-infected cells did not decline in the presence of $15 \mathrm{mM}$ NAC (viability $88.3 \%$ ) or $60 \mu \mathrm{g}$ of AA per $\mathrm{ml}$ (viability $85.4 \%$ ).

The increase in RT activity in CRFK/FIV cells reached a peak of virus production $24 \mathrm{hr}$ after addition of TNF- $\alpha$. In contrast, NAC or AA treated cultures showed a striking inhibition of RT production. A noticeable drop $(47.6 \%$ inhibition) occurred after culturing the cells for $24 \mathrm{hr}$ with NAC under TNF- $\alpha$ influence, followed by a progressive decline in RT levels. In the presence of $60 \mu \mathrm{g}$ of AA per $\mathrm{m} l$, the RT level in the culture supernatant of CRFK/FIV cells treated with TNF- $\alpha$ decreased by $50 \%, 24 \mathrm{hr}$ after treatment (Fig. 2A).

As indicated by the morphology, the cell death induced in CRFK/FIV cells after treatment with TNF- $\alpha$ was found to be due to apoptosis (data not shown). Also, a characteristic DNA fragmentation of 180-200-bp 
A

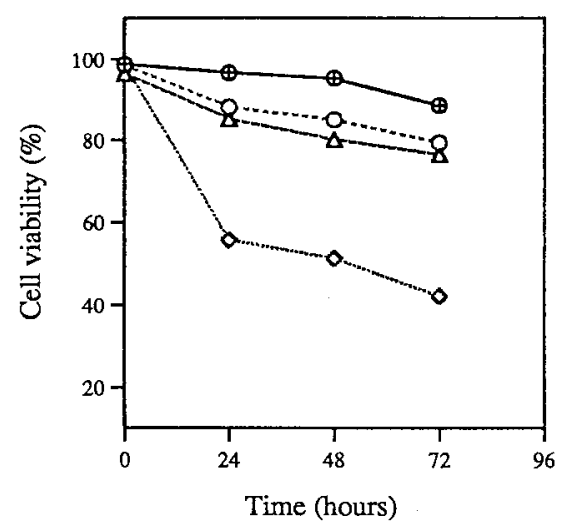

B

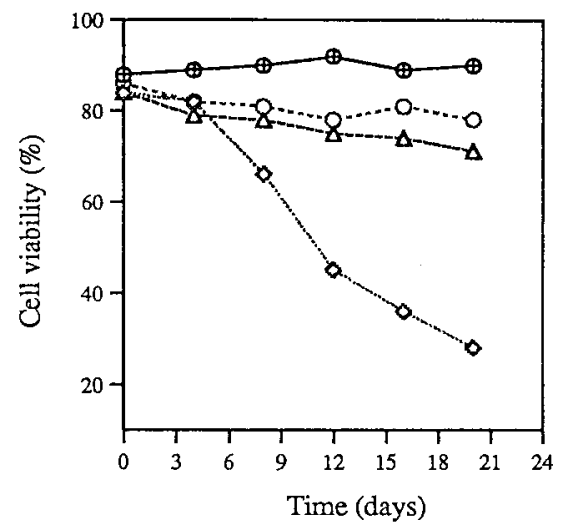

Fig. 1. Effect of NAC and AA on cell viability. (A) $-\oplus$ - CRFK/FIV, $-\triangleright-$ CRFK/FIV treated with TNF- $\alpha$, - - - CRFK/FIV treated with TNF- $\alpha$ and NAC, $-\triangle$ - CRFK/FIV treated with TNF- $\alpha$ and AA. (B) $-\oplus$ - Fel-039, $-\diamond$ - Fel-039/FIV, - $\bigcirc$ - Fel-039/FIV treated with NAC, $-\triangle$ Fel-039/FIV treated with AA. Triplicate cultures were sampled for trypan blue exclusion test 0, 24, 48 and $72 \mathrm{hr}$ after treatment with TNF- $\alpha$ and antioxidants in CRFK/FIV cells, and every third day after infection with FIV in Fel-039 cells.
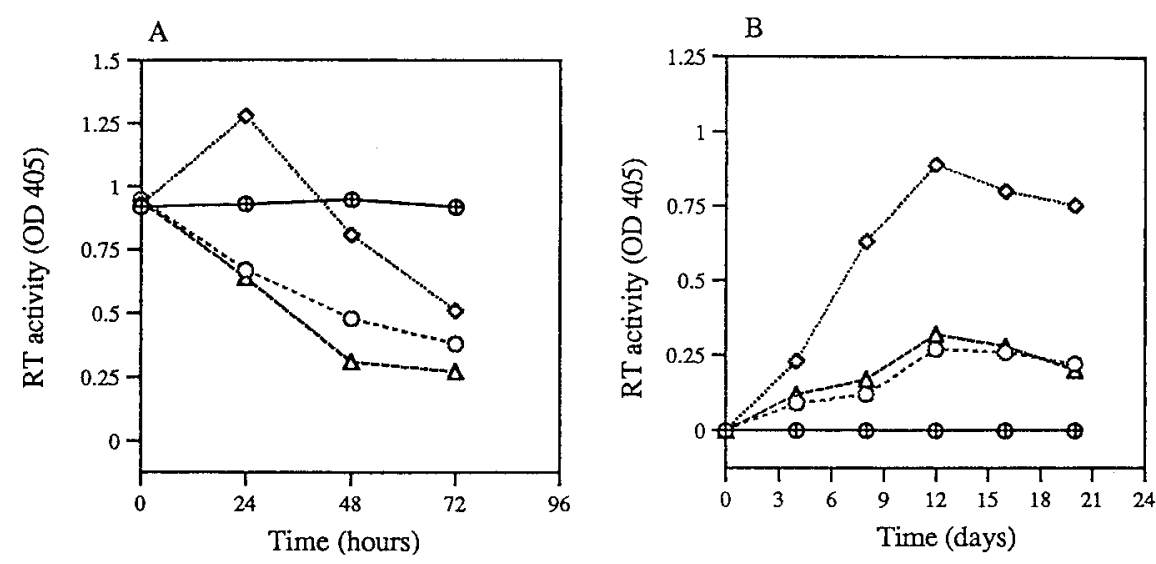

Fig. 2. Inhibition of RT activity in CRFK/FIV and Fel-039/FIV cells by NAC and AA. (A) - $\oplus$ CRFK/FIV, $-\diamond$ - CRFK/FIV treated with TNF- $\alpha,-\bigcirc-$ CRFK/FIV treated with TNF- $\alpha$ and NAC, $-\triangle$ - CRFK/FIV treated with TNF- $\alpha$ and AA. (B) $-\oplus$ - Fel-039, $-\diamond$ - Fel-039/FIV, $-\bigcirc-$ Fel-039/FIV treated with NAC, $-\triangle$ - Fel-039/FIV treated with AA. Triplicate cultures were sampled for RT assay $0,24,48$ and $72 \mathrm{hr}$ after treatment with TNF- $\alpha$ and antioxidants in CRFK/FIV cells, and every third day after infection with FIV in Fel-039 cells.

nucleosomal laddering was observed in the infected cells (Fig. 3A). These finding indicated that the cell death in CRFK/FIV cells induced by TNF- $\alpha$ was mediated via apoptosis. In contrast, as showed by the DNA fragment assay, the treatment with $15 \mathrm{mM} \mathrm{NAC}$ or $60 \mu \mathrm{g}$ of AA per $\mathrm{m} l$ inhibited the progression of apoptosis in cell cultures exposed to TNF- $\alpha$ (Fig. 3A).

To examine the effect of NAC on the redox-state of the cells, measurement of intracellular GSH was carried out. The results obtained indicate that GSH level in FIV-infected cells was significantly decreased $(40.9 \%)$ in comparison with that in uninfected controls. The GSH level in CRFK/ FIV cells showed further decrease after treatment with TNF$\alpha$. Addition of $15 \mathrm{mM}$ NAC significantly restored the GSH level (77.2\% in comparison to the control) of the CRFK/
FIV cells treated with TNF- $\alpha$. Addition of $60 \mu \mathrm{g}$ of AA per $\mathrm{m} l$ also significantly restored the GSH content in these CRFK/FIV cells treated with TNF- $\alpha$ (Fig. 4A).

Effects of NAC and AA in Fel-039 cells acutely infected with FIV: Cytotoxic effect was not observed in Fel-039 cells after treatment with concentrations less than $30 \mathrm{mM}$ NAC or less than $160 \mu \mathrm{g}$ of AA per $\mathrm{ml}$ (data not shown). Therefore, the concentrations of $15 \mathrm{mM} \mathrm{NAC}$ and $60 \mu \mathrm{g}$ of AA per $\mathrm{m} l$ were chosen for analysis in Fel-039 cells.

In order to determine the kinetics of FIV growth, RT activity was examined. As showed in Fig. 2B, RT level increased slowly and then reached a peak 12 days postinfection in association with the decrease in cell viability (Fig. 1B).

The cell viability of acutely infected Fel-039 cells (Fig. 
A

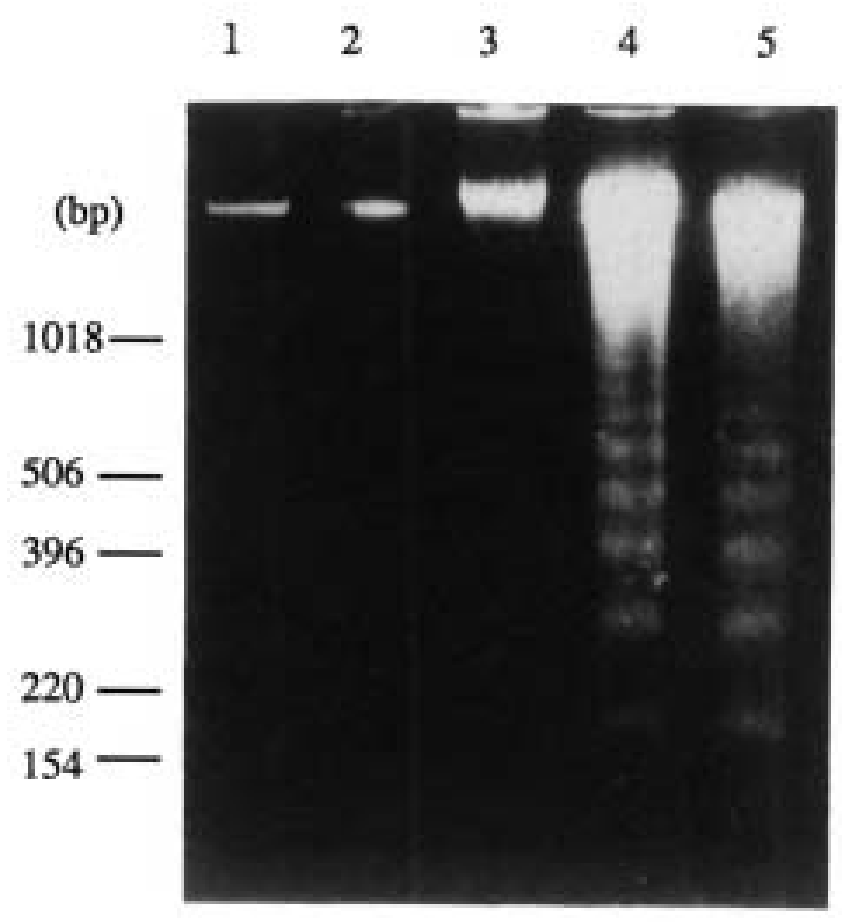

B

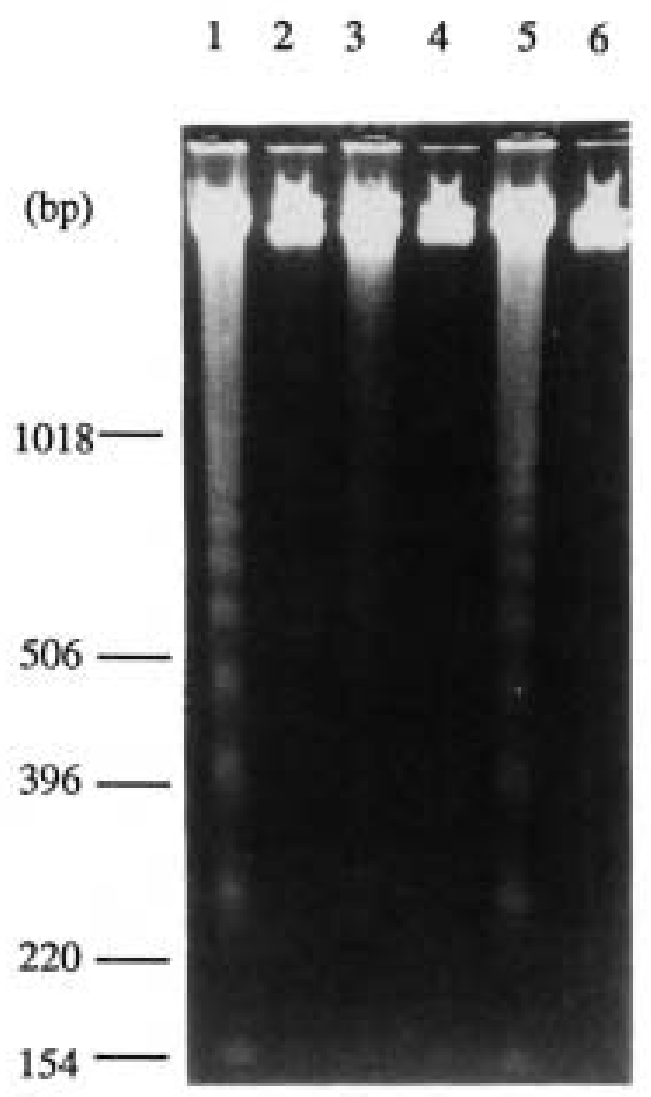

Fig. 3. DNA fragmentation assay in CRFK/FIV and Fel-039 cells. (A) DNA samples extracted from CRFK cells 24 hr after treatment with TNF- $\alpha$ and antioxidants, were subjected to electrophoresis in $1.8 \%$ agarose gel. Lane 1 , uninfected CRFK cells treated with TNF- $\alpha$; lane 2, CRFK/FIV cells treated with TNF- $\alpha$ and NAC; lane 3, CRFK/FIV cells treated with TNF- $\alpha$ and AA; lanes 4 and 5, CRFK/FIV cells treated with TNF- $\alpha$. (B) DNA samples extracted from Fel-039 cells 12 days after infection with FIV were subjected to electrophoresis in 1.8\% agarose gel. Lane 1, 3 and 5, Fel-039/FIV cells; lane 2, Fel-039/FIV cells treated with NAC; lane 4, Fel-039/FIV cells treated with AA; lane 6, uninfected Fel-039 cells.

1B) dropped by $44 \%$ in comparison with that of the uninfected control 12 days after infection with FIV. In the parallel experiment, a significative percentage of cells remained viable in FIV-infected Fel-039 cells in the presence of NAC (viability $81 \%$ ) or AA (viability $74 \%$ ).

When the acutely infected Fel-039 cells were cultured in the presence of NAC or AA, the RT value in the culture supernatant 12 days after infection was reduced by $69.6 \%$ and $64 \%$, in comparison with the non-treated control cells, for NAC and AA treatments respectively (Fig. 2B). Since the concentrations of NAC and AA did not induce the inhibition of cell growth in Fel-039 cells, the inhibition of virus replication was shown not to be due to the cytotoxic effect of these antioxidants.

The cell death induced in Fel-039 cells by FIV infection showed morphology characteristic to apoptosis (data not shown). Gel electrophoresis of the DNA of the FIV-infected Fel-039 cells showed DNA ladders, whose sizes were multiple of 180-200-bp. The DNA fragmentation was significantly inhibited by the treatment with NAC or AA, indicating their effect on the inhibition of apoptosis in Fel039 cells infected with FIV (Fig. 3B).

In order to measure the acid-soluble thiol in Fel-039 cells, the intracellular GSH level was examined. As shown in Fig. 4B, intracellular GSH levels markedly decreased by 45.6\% when the Fel-039 cells were infected with FIV. Nevertheless, in the Fel-039 cells infected with FIV, the treatment of NAC or AA restored the GSH levels throughout the experiment $(90.3 \%$ and $88.5 \%$ respectively).

\section{DISCUSSION}

The use of two different antioxidants, NAC and AA, resulted in inhibition of apoptosis and FIV replication in chronically and acutely infected cells in this study.

We demonstrated the decreased level of intracellular GSH in the chronically FIV-infected CRFK cells after TNF- $\alpha$ treatment and acutely FIV-infected Fel-039 cells. Depletion 
A

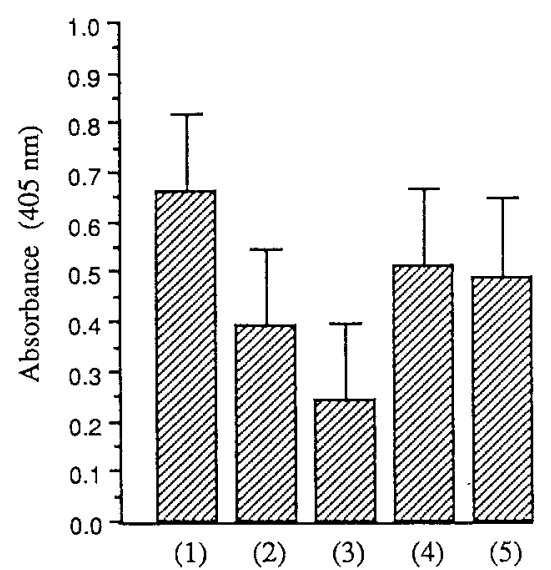

B

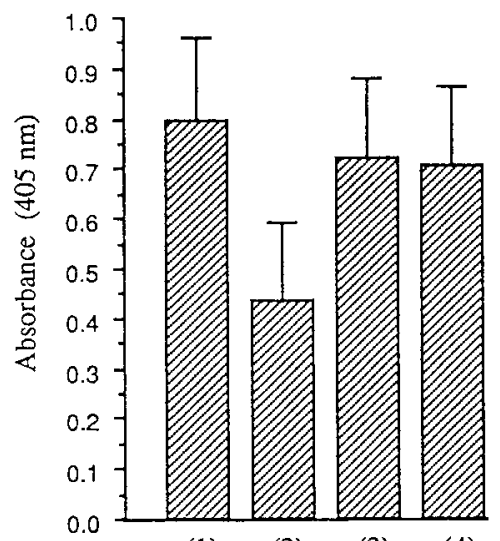

(1)

(2)

(3)

(4)

Fig. 4. GSH levels in CRFK and Fel-039 cells. (A) (1) CRFK cells, (2) CRFK/FIV cells, (3) CRFK/FIV cells treated with TNF- $\alpha$, (4) CRFK/FIV cells treated with TNF- $\alpha$ and NAC, (5) CRFK/FIV cells treated with TNF- $\alpha$ and AA. (B) (1) Fel-039 cells, (2) Fel-039/FIV cells, (3) Fel-039/FIV cells treated with NAC, (4) Fel-039/FIV cells treated with AA. The columns represent the means \pm standard deviation of three separate experiments assayed $24 \mathrm{hr}$ after treatment with TNF- $\alpha$ and antioxidants in CRFK/FIV cells and 12 days after infection with FIV in Fel-039 cells.

of GSH by $10-40 \%$ was shown to inhibit T-cell proliferation and activation $[13,14,38]$. A low level of GSH potentiates sensitivity to TNF- $\alpha$, which has a direct stimulatory effect on HIV expression and also increases susceptibility to oxidative effects [20]. In addition, Zenger et al. [45] found that cultures of feline astroglia cells infected with FIV showed significant decrease of intracellular GSH levels. Supplementation of GSH has been shown to exert no inhibitory effects on HIV production in vitro [19]. One explanation for this is that the supplemented GSH cannot enter the cells unless it is degraded or provided in an acetylated form [25]. A simple and straightforward approach to increase intracellular GSH concentration is to use inducers of GSH, such as NAC or AA, which protect the cells against oxidative stresses. We measured the GSH content in FIV-infected cells cultured in the presence of NAC or AA, and found that it was significatively higher than that in the cells without these agents. In the in vivo system, Zimmerman et al. [46] showed that rats which were administered with lethal dose of TNF- $\alpha$ could be rescued by co-administration of NAC. Therefore, it is highly plausible to administer NAC as a therapeutic agent in FIV and HIV infections.

We demonstrated that cell death or apoptosis in FIV infected cells was halted by addition of NAC or AA. In the HIV system, addition of NAC or AA to an infected cell culture inhibited TNF- $\alpha$ through inhibition of NF- $\kappa$ B. Transcription of TNF- $\alpha$ might be one of the targets directly affected by variations of the cysteine supply and/or intracellular GSH levels $[19,20]$. Increasing the level of $\mathrm{GSH}$, which is a substrate for the glutathione peroxidase enzyme, removes the intracellular oxygen free radicals [10].

These studies indicate that to prevent apoptosis effectively, an inhibitor which neutralizes oxygen radicals would be an important asset. On the basis of our work, we suggest that antioxidants such as NAC or AA can inhibit the oxidant stimulation which leads to apoptosis through $\mathrm{NF}-\kappa \mathrm{B}$ activation. The precise mechanisms by which antioxidants block NF- $\kappa \mathrm{B}$ activation remain unclear, but may be related to the scavenging of oxygen radicals [43], as reactive oxygen intermediates appear to participate in the activation of the cytoplasmic precursor of NF- $\kappa \mathrm{B}$. Oxidative stress has recently been suggested to be involved in the signal transduction pathway that leads to the activation of $\mathrm{NF}-\kappa \mathrm{B}$ and subsequent HIV transcription [39].

We found that GSH supplementation through addition of NAC and AA significantly inhibited the increase of RT activity in both acute and chronic FIV-infection cell systems used in this study. These findings are consistent with the observations by Roederer et al. [34], in which they found that NAC inhibited HIV replication in cytokine-stimulated cells but not in unstimulated cells. In Fel-039 cells acutely infected with FIV, NAC and AA substantially inhibited the viral replication in this study. For models of chronic infection, we used the CRFK/FIV cell line, which produced a minimal amount of virus without stimulation with TNF- $\alpha$. We showed that NAC inhibited the replication of FIV by the inhibition of TNF- $\alpha$ on the CRFK/FIV cells. Poli et al. [33] also demonstrated that NAC inhibited the HIV replication which was enhanced by IL-6. These results could suggest that NAC may be effective in maintaining viral latency by inhibiting the enhancement of lentivirus replication by several stimulants. The mechanism by which NAC or AA inhibits FIV replication is not fully understood. One of the cellular components that may underlie this phenomenon is NF- $\kappa \mathrm{B}$. It is conceivable that oxygen 
radicals can directly and specifically activate $\mathrm{NF}-\kappa \mathrm{B}$ in the cells and consequently stimulate FIV replication. The antioxidants NAC and AA were shown to be able to block $\mathrm{NF}-\kappa \mathrm{B}$ binding activity and HIV replication [24]. Agents that interfere with $\mathrm{NF}-\kappa \mathrm{B}$ transcription activity may therefore have an inhibitory effect on viral replication. Inhibition of FIV replication by NAC and AA seems to be a consequence of the oxygen radical-scavenging effect of the thiol group of NAC through the inhibition of NF- $\kappa$ B activity. This hypothesis can be supported by the observations of Kawaguchi et al. [21], in which they showed that FIV replication in CRFK and feline T-lymphoblastoid cells are strongly dependent on the interaction of the nuclear factor(s) that binds to the $\mathrm{C} / \mathrm{EBP}$ site within the FIV Petaluma strain long terminal repeat (LTR).

We would suggest that agents that interfere with FIV virus replication may therefore have an important role in controling cell death by apoptosis. Certainly, FIV infection has an early direct effect upon T-cell subsets in the cat [2], with a selective loss of the CD4+ cells [3]. Thus, FIV severely impairs the immune response and increases the susceptibility to opportunistic secondary pathogens $[9,44]$. Our finding has demonstrated that antioxidants could contribute to the preservation of T-lymphocytes, tending to improve the immunosuppression in FIV-infected cats.

Since the FIV infection induces the decrease of intracellular GSH level, exogenous thiol sources can effectively block the stimulation of viral replication. The NAC effectively blocked the cytokine-induced production of the virus from latently infected cells. Furthermore, besides inhibiting the stimulation of FIV, thiol replacement therapy may alleviate the distressing wasting that often accompanies FIV infection. From these observations, we suggest that agents which raise intracellular GSH levels may have a therapeutic value in the immunosuppressive conditions in FIV infection.

NAC and AA, both have a long history of use in humans as well in animals, and its safety and pharmacological actions are well established. This type of therapy may have many positive effects on inhibition of viral growth and apoptosis in the immune system in FIV-infected cats, which may improve the clinical symptoms of these animals. Furthermore, the FIV and cat system may provide invaluable insight into the mechanism of pathogenesis and define novel approaches to elicit protective therapy in HIV infection and AIDS in humans.

ACKNOWLEDGMENTS. This work was supported by grants from the Ministry of Education, Science, Sports and Culture and from the Ministry of Health and Welfare in Japan. This work was also supported by a Grant-in-Aid of Recombinant Cytokine's Project provided by the Ministry of Agriculture, Forestry and Fisheries, Japan (RCP19883110).

\section{REFERENCES}

1. Ackley, C.D., Yamamoto, J.K., Levy, N., Pedersen, N.C. and Cooper, M. D. 1990. Immunologic abnormalities in pathogen-free cats experimentally infected with feline immunodeficiency virus. Virology 64: 5652-5655.

2. Bishop, S.A., Williams, N.A., Gruffydd-Jones, T.J., Harbour, D.A. and Stokes, C.R. 1993. Impaired T-cell priming in cats infected with feline immunodeficiency virus (FIV). AIDS 6: 287-293.

3. Bishop, S.A., Gruffydd-Jones, T.J., Harbour, D.A. and Stokes, C.R. 1993b. Programmed cell death (apoptosis) as a mechanism of cell death in peripheral blood mononuclear cells from cats infected with feline immunodeficiency virus (FIV). Clin. Exp. Immunol. 93: 65-71.

4. Bissell, M.J., Hatie, C., Farson, D.A., Schwarz, R.I. and Soo, W.J. 1980. Ascorbic acid inhibits replication and infectivity of avian RNA tumor virus. Proc. Natl. Acad. Sci. U.S.A. 77: 2711-2715.

5. Boman, G., Backer, U., Larsson, S., Melander, B. and Wahlander, L. 1983. Oral acetilcysteine reduces exacerbation rate in chronic bronchitis : report of a trial organized by the Swedish Society for pulmonary diseases. Eur. J. Respir. Dis. 64: 405-415.

6. British Thoracic Society Research Committee. 1985. Oral Nacetylcysteine and exacerbation rates in patients with chronic bronchitis and severe airways obstruction. Thorax 40: 832835.

7. Brown, W.C., Bissey, L. and Logan, K.S. 1991. Feline immnunodeficiency virus infects both CD4 and CD8 T lymphocytes. J. Virol. 65: 3359-3364.

8. Crandell, R.A., Fabricant, C.G. and Nelson-Rees, W.A. 1973. Development, characterization, and viral susceptibility of a feline (Felis catus) renal cell line (CRFK). In vitro 9: 176185.

9. Dawson, S., Smyth, N.R. and Bennrt, M. 1990. Effect of primary-stage feline immunodeficiency virus infection on subsequent feline calicivirus vaccination and challenge in cats. AIDS 5: 747-750.

10. De-Vries, N. and De-Flora, S. 1993. N-acetyl-l-cysteine. J. Cell. Biochem. 17: 270-277.

11. Dow, S.W., Poss, M.L. and Hoover, E.A. 1990. Feline immunodeficiency virus: a neurotropic lentivirus. J. Acq. Immun. Def. Syndr. 3: 658-668.

12. Eck, H.P., Gmunder, H., Hartmann, M., Petzoldt, D., Daniel, V. and Droge, W. 1989. Low concentration of acid-soluble thiol (cysteine) in the blood plasma of HIV-1-infected patients. Biol. Chem. H.-S. 370: 101-108.

13. Fidelus, R.K. and Tsan, M.F. 1986. Enhancement of intracellular glutathione promotes lymphocyte activation by mitogen. Cell. Immunol. 97: 155-159.

14. Fischman, C.H., Udey, M.C., Kurtz, M. and Wedner, J.H. 1981. Inhibition of lectin-induced lymphocyte glutathione inhibits an early event in the activation sequence. J. Immunol. 127: 2257-2261.

15. Fuchs, D., Gruber, A., Uberall, F. and Wachter, H. 1994. Oxidative stress and apoptosis. Immunol. Today 15: 496-499.

16. Gorman, A.M., McGowan, A., O'Neill, C. and Cotter, T. 1996. Oxidative stress and apoptosis in neurodegeneration. 
Neurol. Sci. 139: 45-52.

17. Greenspan, H.C. and Aruoma, O.I. 1994. Oxidative stress and apoptosis in HIV infection: a role for plant-derived metabolites with synergistic antioxidants activity. Immunol. Today 15: 209-213.

18. Halliwell, B. and Cross, C.E. 1991. Commentary: reactive oxygen species, antioxidants, and acquired immunodeficiency syndrome - Sense or speculation. Arch. Intern. Med. 151: 2931.

19. Harakeh, S. and Jariwalla, R. 1991. Comparative study of the anti-HIV activities of ascorbate and thiol-containing reducing agents in chronically HIV-infected cells. Am. J. Clin. Nutr. 54: 1231-1235.

20. Harakeh, S., Niedzwiecki, A. and Jariwalla, R. 1994. Mechanistic aspects of ascorbate inhibition of human immunodeficiency virus. Chem. Biol. Interact. 91: 207-215.

21. Kawaguchi, Y., Tomonaga, K., Maeda, K., Ono, M., Miyazawa, T., Kohmoto, M., Tohya, Y. and Mikami, T. 1995. The C/EBP site in the feline immunodeficiency virus (FIV) long terminal repeat (LTR) is necessary for its efficient replication and is also involved in the inhibition of FIV LTRdirected gene expression by pseudorabies virus ICP4. Virology 208: 492-499.

22. Lin, D.S., Bowman, D.D., Jacobson, R.H., Barr, M.C., Fevereiro, M., Williams, J.R., Noronha, F.M.O., Scott, F.W. and Avery, R.J. 1990. Suppression of lymphocyte blastogenesis to mitogens in cats experimentally infected with feline immunodeficiency virus. Vet. Immunol. Immunopathol. 26: 183-189.

23. Mathieu, J., Chancerelle, Y., Herodin, F., Multon, E., Drouet, M., Mestries, J.C. and Kergonou, J.F. 1996. Oxidative stress and apoptosis. Ann. Pharm. Fr. 54: 193-201.

24. McGowan, A.J., Fernandes, R.S., Samali, A. and Cotter, T.G. 1996. Anti-oxidants and apoptosis. Biochem. Soc. Trans. 24: 229-233.

25. Meister, A., Anderson, M.E. and Hwang, O. 1986. Intracellular cysteine and glutathione delivery systems. J. Am. Coll. Nutr. 5: 137-151.

26. Miyazawa, T., Furuya, T., Itagaki, S., Tohya, Y., Nakano,K.,Takahashi, E. and Mikami, T. 1989. Preliminary comparisons of the biological properties of two strains of feline immunodeficiency virus (FIV) isolated in Japan with FIV Petaluma strain isolated in the United States. Arch. Virol. 108: 59-68.

27. Moldeus, P., Cotgreave, I.A. and Bergren, M. 1986. Lung protection by a thiol-containing antioxidant: $\mathrm{N}$-acetylcysteine. Respiration 50: 31-42.

28. Ohno, K., Nakano, T., Matsumoto, Y., Watari,T., Goitsuka, R., Nakayama, H., Tsujimoto, H. and Hasegawa, A. 1993. Apoptosis induced by tumor necrosis factor in cells chronically infected with feline immunodeficiency virus. J. Virol. 67: 2429-2433.

29. Ohno, K., Okamoto, Y., Miyazawa, T., Mikami, T., Watari,T., Goitsuka, R., Tsujimoto, H. and Hasegawa, A. 1994. Induction of apoptosis in a T-lymphoblastoid cell line infected with feline immnunodeficiency virus. Arch. Virol. 135: 153158.

30. Pauling, L. 1976. For the best health - How much vitamin C do you need? Penn. Den. J. 43: 53-56.

31. Pedersen, N.C. 1990. Feline immunodeficiency virus infection. pp. 165-183 In: Animal Models in AIDS (Shellekens, H. and Horzinek, M. C. eds.), Elsevier, Amsterdam.

32. Pedersen, N.C., Ho, E.W., Brown, M.L. and Yamamoto, J.K. 1987. Isolation of a T lymphotropic virus from domestic cats with an immunodeficiency like syndrome. Science 235: 790793.

33. Poli, G., Bressler, P., Kinter, A., Duh, E., Timmer, W.C., Rabson, A., Justement, J.S., Stanley, S. and Fauci, A.S. 1990. Interleukin 6 induces human immunodeficiency virus expression in infected monocytic cells alone and in synergy with tumor necrosis factor-alpha by transacriptional and post-transcriptional mechanisms. J. Exp. Med. 172: 151-158.

34. Roederer, M., Ela, S.W., Frank, J.T., Staal, F.J. and Herzenberg, L. 1992. N-acetylcysteine: A new approach to anti-HIV therapy. AIDS Res. Hum. Retrovir. 8: 209-217.

35. Roederer, M., Staal, F.J., Raju, P.A., Ela, S.W., Herzenberg, L. and Herzenberg, L. 1990. Cytokine-stimulated HIV replication is inhibited by $\mathrm{N}$-acetylcysteine. Proc. Natl. Acad. Sci. U.S.A. 87: 4884-4888.

36. Shin, J.T., Barbeito, L., MacMillan-Crow, L.A., Beckman, J.S. and Thompson, J.A. 1996. Acidic fibroblast growth factor enhances peroxynitrite-induced apoptosis in primary murine fibroblasts. Arch. Biochem. Biophys. 335: 32-41.

37. Stone, I. 1974. More on ascorbate. Med. J. Austral. 1: 972.

38. Suthanthiran, M., Anderson, M.E., Sharma, V. and Meister, A. 1990. Glutathione regulates activation-dependent DNA synthesis via the CD2 and CD3 antigens. Proc. Natl. Acad. Sci. U.S.A. 87: 3343-3347.

39. Suzuki, Y., Aggarwal, B. and Packer, L. 1992. $\alpha$-Lipoic acid is a potent inhibitor of NFkB activation in human T cells. Bioch. Bioph. Res. Comm. 189: 1709-1715.

40. Tietze, F. 1969. Enzymic method for quantitative determination of nanogram amounts of total and oxidized glutathione. Anal. Biochem. 27: 502-522.

41. Tokunaga, K., Nishino, Y., Oikawa, H., Ishihara, C., Mikami, T. and Ikuta, K. 1992. Altered cell tropism and cytopathicity of feline immunodeficiency viruses in two different feline CD4-positive, CD8-negative cell lines. J. Virol. 66: 3893 3898.

42. Walker, N.I., Harmon, B.V., Gobe, G.C. and Kerr, J.F. 1988. Patterns of cell death. Meth. Achiev. Exp. Pathol. 13: 18-25.

43. Wyllie, A.H. 1987. Apoptosis: cell death in tissue regulation. J. Pathol. 153: 313-316.

44. Yamamoto, J.K. and Hansen, H. 1989. Epidemiologic and clinical aspects of feline immunodeficiency virus (FIV) infection in cats from the continental United States and Canada and possible mode of transmission. J. Am. Vet. Med. Assoc. 194: 213-220.

45. Zenger, E., Collison, E.W., Barhoumi, R., Burghardt, R.C., Danave, I.R. and Castiglioni, E.T. 1995. Laser cytometric analysis of FIV-induced injury in astroglia. Glia 13: 92-100.

46. Zimmerman, R.J., Marafino, B.J. Jr, Chan, A., Landre, P. and Winkelhake, J.L. 1989. The role of oxidant injury in tumor cell sensitivity to recombinant human tumor necrosis factor in vivo. Implications for mechanism of action. J. Immunol. 142: 1405-1409. 